\title{
Sintesis dan karakterisasi bioplastik dari pati ubi nagara (Ipomoea batatas $L$ ) dengan kaolin sebagai penguat
}

\section{Synthesis and characterization of bioplastic from nagara sweet potato (Ipomoea batatas $L$ ) with kaolin as reinforcement}

\author{
Sunardi $^{a, b, \star}$, Yulia Susanti ${ }^{a}$, Kamilia Mustikasari $^{a}$ \\ ${ }^{a}$ Chemistry Department, Faculty of Mathematics and Natural Sciences, \\ Lambung Mangkurat University, Banjarbaru 70714, Indonesia \\ 'Wetland-Based Materials Research Group, Lambung Mangkurat University, \\ Banjarbaru 70714, Indonesia \\ *E-mail: sunardi@ulm.ac.id
}

Diterima 02 April 2019, Direvisi 26 Juni 2019, Disetujui 18 Oktober 2019

\begin{abstract}
ABSTRAK
Ubi nagara (Ipomoea batatas $L$ ) merupakan salah satu sumber pati yang memiliki potensi besar untuk dimaanfatkan sebagai matriks pembuatan bioplastik untuk menggantikan plastik sintetik. Penambahan material anorganik ke dalam bioplastik sebagai penguat dapat memperbaiki sifat plastik. Penelitian ini bertujuan untuk mengevaluasi pengaruh penambahan kaolin terhadap karakteristik bioplastik dari pati ubi nagara. Sintesis bioplastik dilakukan dengan metode melt intercalation dengan variasi konsentrasi kaolin sebesar 0\%,5\%,10\%, 15\%, 20\%, dan 30\% (b/b). Bioplastik yang dihasilkan dianalisis kadar air, ketebalan, laju transmisi uap air, ketahanan air, kelarutan, biodegradasi, analisis gugus fungsional menggunakan FTIR, kuat tarik dan elongasinya. Berdasarkan hasil penelitian yang diperoleh, penambahan kaolin mempengaruhi semua karakteristik bioplastik yang dihasilkan. Nilai kuat tarik bioplastik yang dihasilkan meningkat dengan bertambahnya kaolin yang ditambahkan. Konsentrasi kaolin optimum dalam pembuatan bioplastik adalah pada penambahan 30\% (b/b) kaolin dengan nilai kuat tarik sebesar $2,194 \mathrm{~N} / \mathrm{mm}^{2}$.
\end{abstract}

Kata Kunci : bioplastik, kaolin, pati, penguat, ubi nagara.

\section{ABSTRACT}

The nagara sweet potato (Ipomoea batatas L) as a starch source has a great potential as bioplastic matrix for synthetic plastic replacement. Addition of inorganic materials into bioplastic as the reinforcement can improve the properties. This study objective was to evaluate the influence of kaolin in the the bioplastic characteristics from sweet potato starch. Bioplastic synthesis was carried out by the melt intercalation method with variations in the amount of kaolin $0 \%, 5 \%, 10 \%, 15 \%, 20 \%$, and $30 \%(\mathrm{w} / \mathrm{w})$. Bioplastics produced were analyzed for moisture content, thickness, water vapor transmission rate, water resistance, solubility, biodegradation, functional group analysis using FTIR, tensile strength and elongation. Based on the research result, the addition of kaolin effected all the characteristics of the bioplastic produced. The values of the tensile strength of the bioplastic produced increased with increasing kaolin added. The results also showed that the optimum kaolin concentration in bioplastics production was $30 \%$ $(w / w)$ kaolin with a tensile strength value of $2.194 \mathrm{~N} / \mathrm{mm}^{2}$.

Keywords : bioplastic, starch, nagara sweet potato, kaolin, reinforcement. 


\section{PENDAHULUAN}

Plastik telah digunakan secara luas dan tidak dapat dipisahkan dari kehidupan kita sehari-hari. Saat ini sampah plastik telah menjadi permasalah besar di dunia. Setiap tahun lebih dari 300 juta ton plastik dipergunakan di seluruh dunia dan lebih dari $50 \%$ dari total plastik yang digunakan adalah plastik kemasan sekali pakai (North \& Halden, 2013). Penggunaan plastik ini memberikan dampak negatif bagi ekologi dan lingkungan karena sulit terdegradasi dan tidak terbarukan (Díez-Pascual \& DíezVicente, 2014). Penggunaan bioplastik merupakan salah satu alternatif solusi untuk mengurangi limbah plastik karena relatif mudah terdegradasi oleh mikroorganisme (Wahyuningtiyas \& Suryanto, 2017).

Pati merupakan polimer yang banyak digunakan sebagai matriks dalam pembuatan bioplastik (Kamsiati, Herawati, \& Purwani, 2017). Bioplastik dari pati banyak dilakukan penelitian karena sifat pati yang ramah lingkungan, mudah diuraikan oleh mikroorganisme, banyak tersedia di alam, dan harganya yang relatif murah (González-Gutiérrez, Partal, GarcíaMorales, \& Gallegos, 2011). Pati dapat diekstraksi dari tanaman seperti jagung, gandum, beras, dan tanaman umbi-umbian seperti kentang, singkong, dan ubi jalar (Ratnayake \& Jackson, 2008). Akan tetapi, pemanfaatan bioplastik yang disintesis dari pati memiliki keterbatasan karena sifat mekanik yang lemah dan sensitive terhadap kelembaban/air (Suryanto, Rahmawan, Sahana, Muhajir, \& Yanuhar, 2019; Xie, Pollet, Halley, \& Averous, 2013). Untuk mengatasi permasalahan tersebut beberapa peneliti menambahkan beberapa pengisi sebagai penguat, misalnya kitosan, nanopartikel besi, selulosa nanokrisal, dan lempung (Balakrishna, Ismail, \& Othman, 2014; Fadeyibi, Osunde, Egwim, \& Idah, 2017; Suryanto, Kharismawan, et al., 2019; Suryanto, Rahmawan, et al., 2019; Zainuddin, Ahmad, \& Kargarzadeh, 2013). Kaolin merupakan salah satu jenis lempung yang banyak digunakan sebagai bahan pengisi berbagai komposit untuk meningkatkan kekuatan mekaniknya.
Penambahan kaolin pada komposit polipropilen/etilen dan propilendiena menunjukkan bahwa penambahan kaolin mampu meningkatkan kekuatan mekanik komposit yang dihasilkan (Salmah, Ismail, \& Bakar, 2005; Suryanto, Kharismawan, et al., 2019; Suryanto, Rahmawan, et al., 2019).

Pada penelitian ini dilakukan sintesis bioplastik dari pati ubi nagara asal Kandangan, Hulu Sungai Selatan, Kalimantan Selatan dengan kaolin lokal asal Tatakan, Rantau, Kalimantan Selatan yang berfungsi sebagai penguat. Penelitian ini bertujuan untuk mengetahui pengaruh penambahan kaolin terhadap karakteristik bioplastik yang dihasilkan serta untuk mendapatkan jumlah kaolin optimum dalam pembuatan bioplastik. Bioplastik yang dihasilkan dianalisis kadar air, ketebalan, laju transmisi uap air, ketahanan air, kelarutan, biodegradasi, analisis gugus fungsional menggunakan FTIR, kuat tarik dan elongasinya.

\section{BAHAN DAN METODE}

\subsection{Alat dan Bahan}

Bahan yang digunakan pada penelitian ini antara lain pati ubi nagara (Ipomoea batatas L), kaolin dari Tatakan Kalimatan Selatan, gliserol, akuades dan silika gel. Beberapa peralatan yang dipergunakan adalah alat gelas, hot-plate stirrer, oven (Memmert), Mikrometer sekrup, Fourier Transfrom Infra-Red Spectroscopy (Shimadu Pestige 21), dan Universal Testing Machine (AND MCT2150).

\subsection{Metode}

\subsubsection{Ekstraksi pati}

Kulit ubi nagara dikupas, bagian dagingnya dicuci dan diparut hingga halus. Setelah halus ditambahkan air dengan perbandingan $1 \mathrm{~kg}$ bahan : 2 liter air. Kain saring digunakan pada proses penyaringan hingga didapatkan ampas dan cairan yang merupakan suspensi pati. Ampas yang dihasilkan ditambahkan air (1 $\mathrm{kg}$ ampas : 2 liter air), kemudian disaring kembali untuk mendapatkan pati. Suspensi pati yang 
dihasilkan pada kedua penyaringan dicampurkan dan diendapkan selama 1 jam. Setelah diendapkan maka akan terpisah bagian pati basah dan air. Pati basah dipisahkan lalu dikeringkan di bawah sinar matahari.

\subsubsection{Pembuatan bioplastik}

Sejumlah tertentu kaolin $(0 \%, 5 \%$, $10 \%, 15 \%$, $20 \%$, dan $30 \%$ dari berat pati) dan gliserol ( $1 \mathrm{~mL}$ ) dicampurkan dalam 100 $\mathrm{mL}$ akuades. Campuran dimasukkan ke dalam gelas piala dan diaduk menggunakan magnetic strirrer selama 50 menit. Sebanyak 5 gram pati ubi nagara ditambahkan ke dalam campuran lalu dipanaskan pada suhu $80-90^{\circ} \mathrm{C}$ sambil dilakukan pengadukan menggunakan stirrer selama 40 menit. Campuran didiamkan terlebih dahulu selama 5 menit sebelum dilakukan pencetakan untuk menghindari adanya gelembunggelembung pada plastik. Sebanyak $5 \mathrm{~mL}$ campuran dituangkan pada cetakan (petridish diameter $9 \mathrm{~cm}$ ) dan dikeringkan dalam oven pada suhu $60^{\circ} \mathrm{C}$ selama 5 jam. Campuran dikeluarkan dari oven dan dibiarkan pada suhu kamar hingga campuran dapat dilepaskan dari cetakan.

\subsubsection{Pengujian sifat mekanik}

Uji kuat tarik bioplastik dilakukan dengan mengikuti (ASTM D638-02a-2002). Sampel dipotong dengan ukuran $2 \mathrm{~cm} \times 10$ $\mathrm{cm}$, kemudian dijepit $1,5 \mathrm{~cm}$ dikedua panjang sisinya. Uji kuat tarik dilakukan menggunakan alat mechanical universal testing machine (AND MCT-2150). Pengujian ini dilakukan sebanyak tiga kali (triplo). Kuat tarik plastik (tensile strength) dan elongasi dapat dihitung berdasarkan Persamaan (1) dan (2).

$$
\begin{aligned}
& \sigma=\frac{\text { Fmaks }}{A o} \\
& \varepsilon=\frac{\Delta l}{l o} \times 100 \%
\end{aligned}
$$

Keterangan:

$\sigma=$ tegangan $\left(\mathrm{N} / \mathrm{m}^{2}\right)$

$\varepsilon=$ regangan/elongasi $(\%)$

$\mathrm{F}_{\text {maks }}=$ gaya maksimal $(\mathrm{N})$

$A_{o}=$ luas penampang $\left(\mathrm{m}^{2}\right)$

$\Delta l \quad=$ perubahan panjang $(\mathrm{m})$
$I_{0}=$ panjang awal $(\mathrm{m})$

\subsubsection{Pengukuran kadar air bioplastik}

Bioplastik yang telah disintesis ditimbang sebanyak 2 gram pada cawan porselin yang telah diketahui beratnya. Bioplastik dalam cawan dimasukkan dalam oven selama 5 jam dengan $100-105^{\circ} \mathrm{C}$. Bioplastik kemudian dikeluarkan dari oven dan dimasukkan ke dalam desikator sampai mencapai suhu kamar kemudian dilakukan penimbangan. Pemanasan dan penimbangan dilakukan berulang sampai didapat berat yang konstan (selisih antara penimbangan berturut-turut 0,002 gram). Berat bioplastik yang hilang dinyatakan sebagai kadar air bioplastik. Persentase kadar air dapat dihitung berdasarkan Persamaan (3).

Kadar Air $(\%)=\frac{w o-w}{w o} \times 100 \%$

Keterangan:

$\mathrm{w}=$ berat bioplastik akhir $(\mathrm{g})$

$\mathrm{w}_{\mathrm{o}}=$ berat bioplastik awal $(\mathrm{g})$

\subsubsection{Pengukuran ketebalan bioplastik}

Ketebalan bioplastik diukur dengan menggunakan alat mikrometer digital. Pengukuran ketebalan dilakukan pada 5 titik yang berbeda. Rata-rata ketebalan dari 5 titik tersebut dinyatakan sebagai nilai ketebalan bioplastik. Ketebalan dinyatakan dalam satuan $\mathrm{mm}$ sedangkan mikrometer yang digunakan memiliki ketelitian 0,01 $\mathrm{mm}$.

\subsubsection{Pengukuran laju transmisi uap air}

Pengukuran laju transmisi uap air dilakukan dengan menggunakan dua buah gelas piala. Gelas piala 1 diisi air lalu ditutup dengan bioplastik diameter $5 \mathrm{~cm}$. gelas piala 1 lalu diletakkan dalam gelas piala 2 yang berisi silika gel yang telah diketahui beratnya, kemudian didiamkan selama 1 jam. Laju transmisi uap air bioplastik dapat dihitung berdasarkan Persamaan (4).

$$
\text { Transmisi Uap Air }=\frac{w}{A}
$$

Keterangan:

$\mathrm{W}=$ Perubahan berat $(\mathrm{g})$

$A=$ Luas Area $\left(\mathrm{cm}^{2}\right)$ 


\subsubsection{Pengukuran ketahanan air}

Bioplastik yang telah ditimbang dimasukan ke dalam gelas piala yang berisi akuades selama 10 detik. Bioplastik kemudian diambil dari gelas piala dan dikeringkan bagian permukaannya dengan tisu setelah itu dilakukan penimbangan. Prosedur perendaman dan penimbangan dilakukan berulang hingga diperoleh berat konstan. Daya serap air bioplastik dapat dihitung berdasarkan Persamaan (5).

Daya serap air $(\%)=\frac{w-w o}{w o} \times 100 \%$

Keterangan:

$\mathrm{w}=$ berat bioplastik basah $(\mathrm{g})$

$\mathrm{w}_{\mathrm{o}}=$ berat bioplastik kering $(\mathrm{g})$

\subsubsection{Pengukuran kelarutan bioplastik}

Bioplastik yang telah ditimbang kemudian direndam dalam akuades selama 24 jam sambil diaduk secara periodik. Setelah 24 jam bioplastik diambil dan dikeringkan pada suhu kamar kemudian ditimbang lagi. Persen kelarutan dapat dihitung berdasarkan Persamaan (6).

Kelarutan $(\%)=\frac{w o-w}{w o} \times 100 \%$

Keterangan:

$\mathrm{W}_{\mathrm{o}}=$ berat bioplastik sebelum dilarutkan $(\mathrm{g})$ $\mathrm{W}=$ berat bioplastik setelah dilarutkan $(\mathrm{g})$

\subsubsection{Pengujian biodegradasi}

Pengujian biodegradasi dilakukan dengan cara sampel bioplastik ditanam kedalam tanah sejauh $5 \mathrm{~cm}$ dari permukaan tanah selama 15 hari. Persen pengurangan berat berdasarkan Persamaan (7).

Pengurangan Berat $(\%)=\frac{w 1-w 2}{w 1} \times 100 \%$

Keterangan:

$\mathrm{w}_{1}=$ berat bioplastik sebelum proses biodegradasi $(\mathrm{g})$

$\mathrm{w}_{2}=$ berat bioplastik setelah proses biodegradasi $(\mathrm{g})$

\subsubsection{Analisis FTIR}

Analisis FTIR dilakukan dengan alat Fourier Transform Infra-Red (Shimadzu 8201) pada rentang bilangan gelombang $4000-400 \mathrm{~cm}^{-1}$.

\section{HASIL DAN PEMBAHASAN}

Penelitian ini diawali dengan proses ekstraksi pati ubi nagara untuk mendapatkan pati yang akan digunakan sebagai matriks dalam pembuatan bioplastik. Ubi nagara yang digunakan sebanyak $5 \mathrm{~kg}$ dan didapatkan pati ubi nagara kering sebanyak 750 gram atau dengan rendemen sebesar $15 \%$. Pati ubi nagara yang diperoleh kemudian digunakan dalam pembuatan bioplastik.

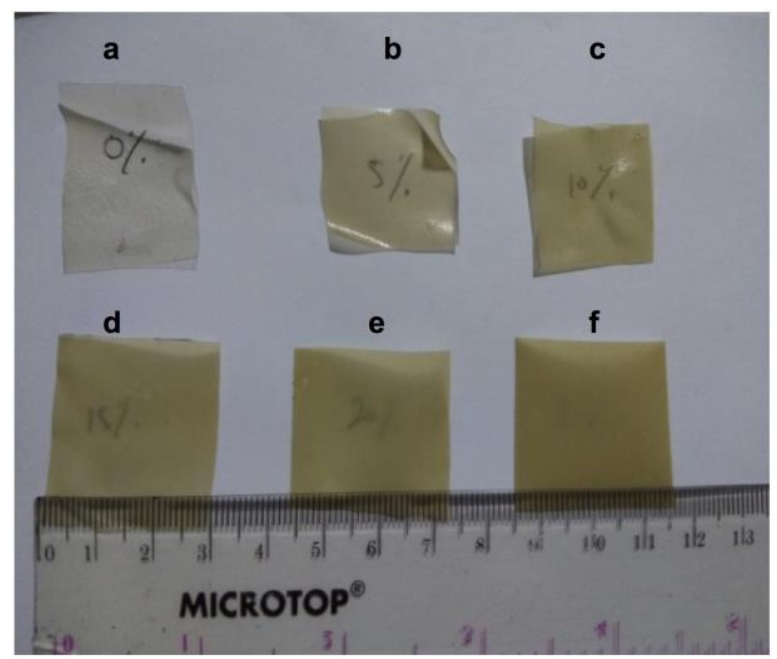

Gambar 1. Foto Bioplastik dengan Variasi Konsentrasi Kaolin (a) 0\%; (b) $5 \%$; (c) $10 \%$; (d) $15 \%$; (e) $20 \%$ dan (f) $30 \%$

Penampakan fisik bioplastik tanpa penambahan kaolin memiliki warna transparan sedangkan penampakan bioplastik dengan peningkatan jumlah kaolin memiliki warna putih kecoklatan yang semakin tidak transparan. Warna semakin tidak transparan ditimbulkan oleh penambahan kaolin yang merupakan serbuk berwarna putih kecoklatan sehingga penambahan kaolin dengan konsentrasi berbeda akan menghasilkan bioplastik dengan kenampakan warna yang berbeda pula (Gambar 1).

Pengujian sifat mekanik dilakukan untuk mengetahui kekuatan bioplastik yang dihasilkan. Pengujian sifat mekanik ini meliputi uji kuat tarik dan elongasi. Kuat tarik (tensile strength) dilakukan untuk mengetahui besarnya gaya tarik 


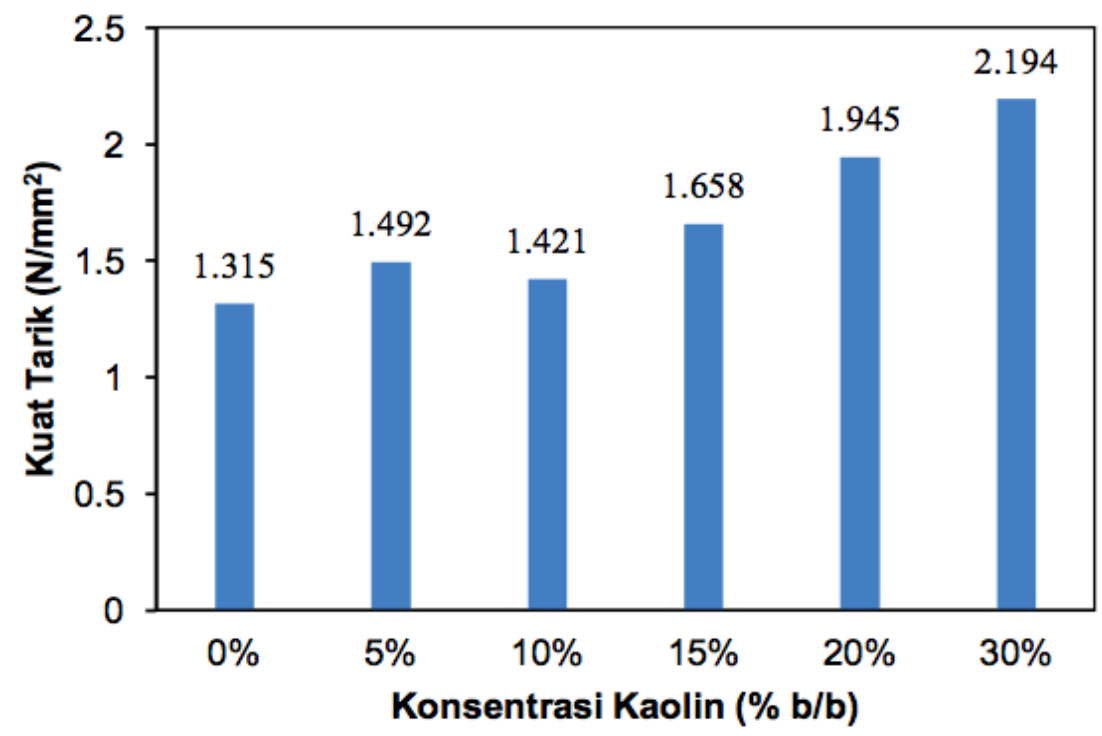

Gambar 2. Hubungan Penambahan Kaolin Terhadap Kuat Tarik Bioplastik

maksimum sebelum bioplastik putus (Akbar, Anita, \& Harahap, 2013).

Gambar 2 menunjukkan bahwa kuat tarik yang dimiliki bioplastik mengalami peningkatan pada penambahan kaolin 5\% (b/b). Peningkatan kuat tarik ini kemungkinan disebabkan karena ikatan hidrogen dalam matriks bioplastik meningkat seiring dengan semakin banyak kaolin yang ditambahkan. Namun, kuat tarik mengalami penurunan pada bioplastik dengan konsentrasi kaolin 10\%. Adanya penurunan nilai kuat tarik ini kemungkinan disebabkan karena distribusi kaolin tidak merata yang ditandai dengan terbentuknya gumpalan pada saat proses pengadukan pembuatan bioplastik. Menurut Kasim, Abral, Asben, \& Sudirman, (2018) pencampuran bahan pengisi berpengaruh terhadap sifat mekanis bioplastik yang dihasilkan. Distribusi bahan pengisi yang tidak homogen akan menurunkan atau mengurangi keefektifan penguatannya. Kemudian seiring dengan peningkatan kaolin sampai konsentrasi $30 \%(\mathrm{~b} / \mathrm{b})$ nilai kuat tarik bioplastik mengalami peningkatan. Peningkatan kuat tarik ini kemungkinan disebabkan karena ikatan hidrogen dalam matriks bioplastik meningkat seiring dengan semakin banyak kaolin yang ditambahkan (Balakrishna et al., 2014). Ikatan hidrogen ini kemungkinan terjadi ketika sebuah molekul atom $O$ yang terdapat dalam kaolin berinteraksi dengan atom $\mathrm{H}$ dari amilosa. Adanya Ikatan hidrogen antar rantai ini diduga akan menyebabkan bioplastik menjadi lebih rapat dan kuat. Bioplastik yang memiliki ikatan hidrogen akan menyebabkan ikatan kimianya semakin kuat sehingga diperlukan energi yang besar untuk memutus ikatan tersebut (Safitri, Riza, \& Syaubari, 2016). Peningkatan kuat tarik ini juga kemungkinan disebabkan karena pori yang ada pada matriks diisi oleh kaolin yang bersifat kuat dan kompak sehingga dihasilkan bioplastik dengan nilai kuat tarik yang tinggi.

Pengujian sifat mekanik yang juga dilakukan dalam penelitian ini yaitu uji elongasi. Elongasi (perpanjangan) merupakan nilai yang menunjukkan pertambahan panjang bioplastik ketika diberikan gaya tarik sampai bioplastik tersebut putus.

Gambar 3 menunjukkan bahwa nilai elongasi mengalami penurunan seiring dengan kenaikan jumlah kaolin yang ditambahkan. Penurunan nilai elongasi ini kemungkinan disebabkan karena meningkatnya ikatan hidrogen dalam matriks bioplastik sehingga jarak ikatan intermolekul semakin menurun. 


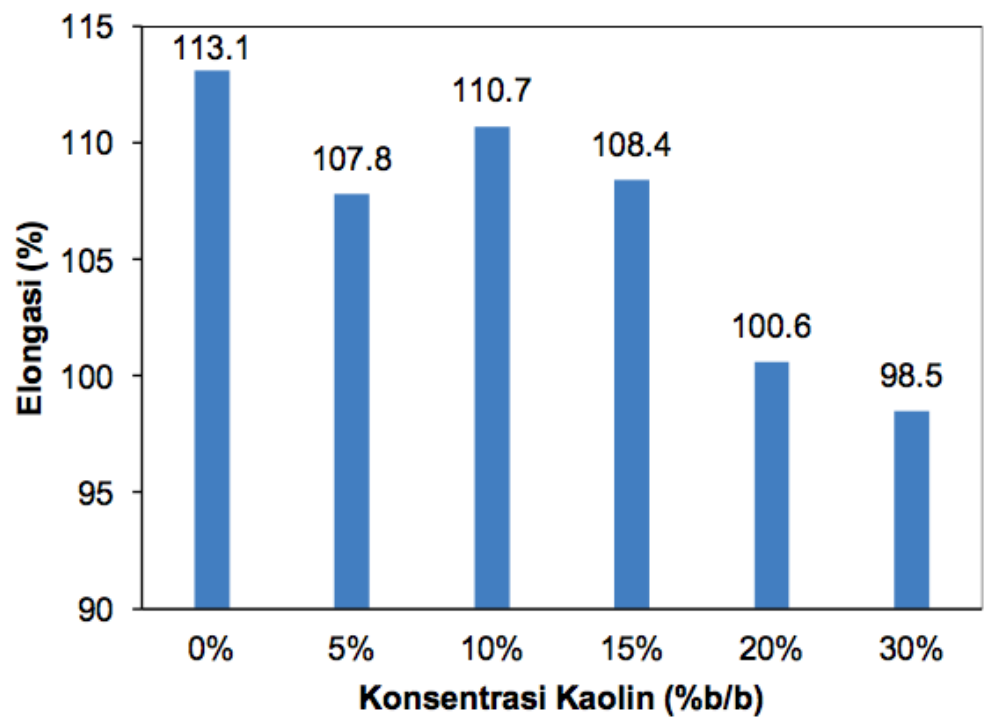

Gambar 3. Hubungan Penambahan Kaolin Terhadap Elongasi Bioplastik

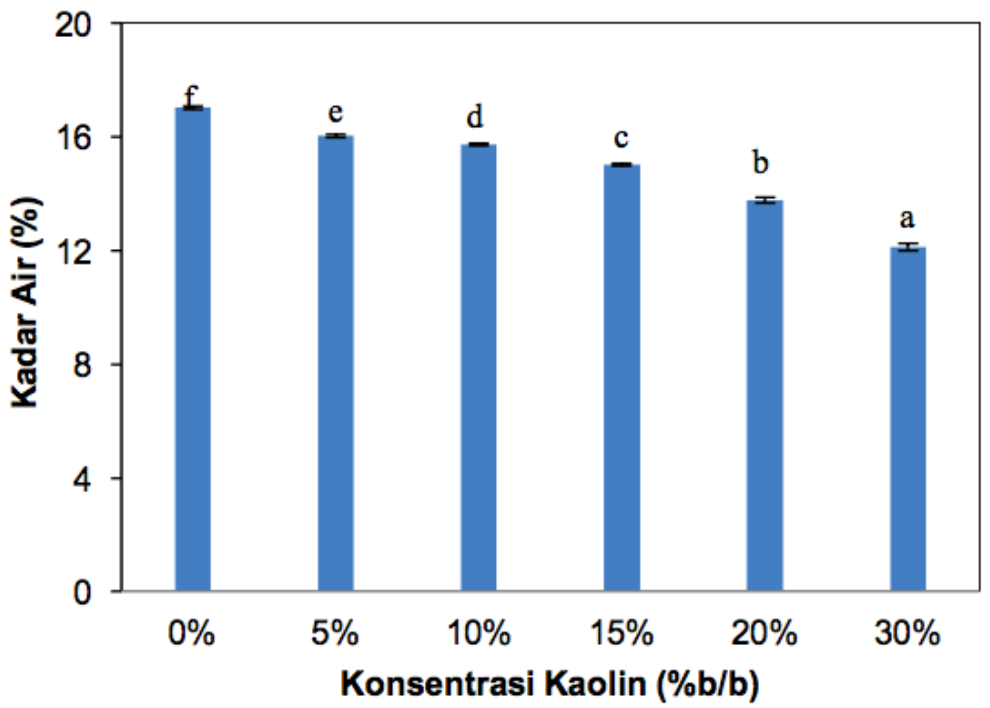

Keterangan: $\quad$ notasi huruf yang berbeda $(a, b, c, d, e, f)$ menunjukkan beda nyata $(p<0,05)$ berdasarkan Uji Tukey HSD

Gambar 4. Hubungan Penambahan Kaolin Terhadap \% Kadar Air Bioplastik

Sifat mekanik (kuat tarik dan elongasi) merupakan salah satu parameter penting dari bioplastik. Sifat mekanik yang baik akan memaksimalkan pemanfaatan bioplastik sebagai kemasan. Dari hasil penelitian menunjukkan bahwa penambahan kaolin mampu memperbaiki sifat mekanik dari bioplastik yang dihasilkan.

Pengukuran kadar air bioplastik dilakukan untuk mengetahui jumlah air yang masih ada dalam bioplastik yang dihasilkan.
Gambar 4 menunjukkan bahwa kadar air yang dimiliki bioplastik pada penelitian ini mengalami penurunan seiring dengan peningkatan jumlah kaolin yang ditambahkan. Penambahan jumlah kaolin yang semakin banyak menyebabkan semakin besar kerapatan polimer penyusun bioplastik tersebut sehingga air yang tertinggal didalamnya semakin sedikit. Menurut Amaliya \& Putri, (2013) bahwa bioplastik dengan polimer yang besar akan menurunkan nilai kadar air. Penurunan kadar air ini juga disebabkan 
karena berkurangnya sifat hidrofilik yang ada pada bioplastik ketika ditambahkan dengan kaolin. Semakin besar jumlah kaolin yang ditambahkan maka akan semakin mengurangi sifat hidrofilik yang ada pada pati dan gliserol. Sifat hidrofilik ini berkurang dikarenakan gugus hidrofilik yang ada pada pati dan gliserol berikatan dengan kaolin.

Pengukuran ketebalan bioplastik dilakukan untuk mengetahui sifat fisik bioplastik berdasarkan jumlah pati, gliserol, dan kaolin yang ditambahkan.

Gambar 5 menunjukkan bahwa ketebalan bioplastik semakin meningkat seiring dengan meningkatnya kadar kaolin yang ditambahkan. Peningkatan ketebalan ini kemungkinan disebabkan karena ketika jumlah kaolin yang ditambahkan semakin banyak maka jumlah total padatan bioplastik tersebut juga akan meningkat.

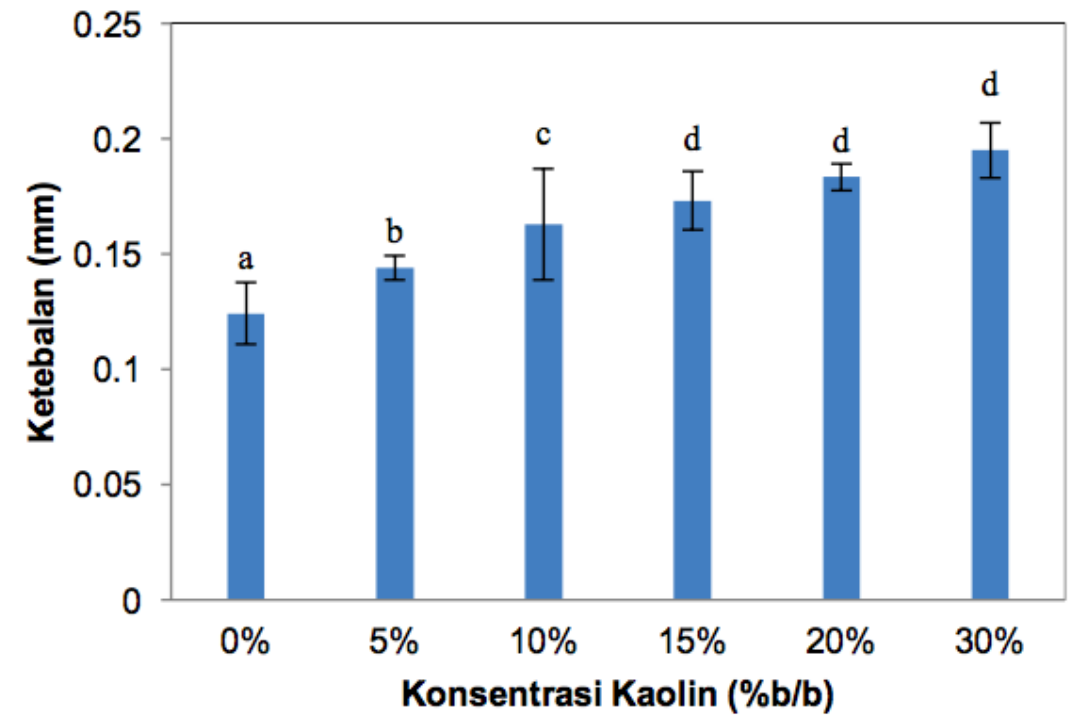

Keterangan: notasi huruf yang berbeda $(a, b, c, d$ menunjukkan beda nyata $(p<0,05)$ berdasarkan Uji Tukey HSD

Gambar 5. Hubungan Penambahan Kaolin Terhadap Ketebalan Bioplastik

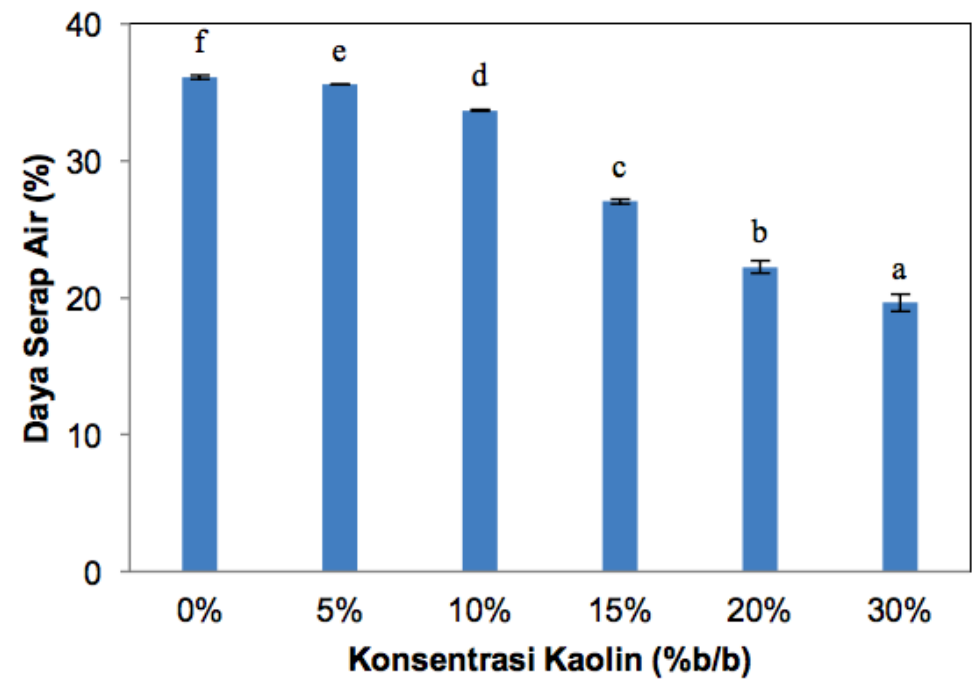

Keterangan: notasi huruf yang berbeda $(a, b, c, d, e, f)$ menunjukkan beda nyata. $(p<0,05)$ berdasarkan Uji Tukey HSD

Gambar 6. Hubungan Penambahan Kaolin Terhadap \% Daya Serap Air Bioplastik 
Pengukuran ketahanan air dilakukan dengan mengukur jumlah air yang diserap oleh bioplastik. Semakin kecil jumlah air yang diserap menunjukkan ketahanan air bioplastik tersebut semakin tinggi. Penurunan nilai daya serap ini kemungkinan disebabkan karena pori-pori bioplastik yang semakin kecil seiring dengan peningkatan jumlah kaolin (Gambar 6). Hal ini sesuai dengan Darni, Lestari, Lismeri, Utami, \& Azwar, (2018) bahwa nilai laju transmisi uap air akan menurun seiring dengan penambahan pengisi yang menutupi pori-pori bioplastik.

Pengukuran kelarutan bioplastik dilakukan untuk mengetahui mudah atau tidaknya bioplastik larut dalam air.

Gambar 7 menunjukkan bahwa nilai kelarutan yang dihasilkan pada penelitian ini mengalami penurunan seiring dengan peningkatan kadar kaolin yang ditambahkan. Dalam penelitian ini sifat hidrofilik yang ada pada bioplastik berkurang ketika ditambahkan dengan kaolin. Semakin besar jumlah kaolin yang ditambahkan maka akan semakin mengurangi sifat hidrofilik yang ada pada pati dan gliserol. Sifat hidrofilik ini berkurang dikarenakan gugus hidrofilik yang ada pada pati dan gliserol berikatan dengan kaolin. Sehingga semakin besar komposisi kaolin yang ditambahkan akan menurunkan kelarutan bioplastik yang dihasilkan. Data kadar kelarutan yang dihasilkan pada penelitian ini menunjukkan bahwa pengaruh penambahan kaolin akan menurunkan tingkat kelarutan bioplastik yang mengindikasikan bahwa bioplastik tersebut semakin kuat.

Bioplastik yang disintesis dari pati ubi nagara dengan kaolin sebagai penguat diuji sifat biodegradasinya dengan dilakukan penguburan dalam tanah dan diamati selama 15 hari.

Gambar 8 menunjukkan bahwa pada hari ke-15 bioplastik telah terdegradasi di atas $75 \%$. Hal ini menunjukkan bahwa bioplastik yang dihasilkan pada penelitian ini termasuk bioplastik yang mudah terdegradasi dan telah sesuai dengan standar plastik biodegradable yang harus terurai kurang dari 180 hari (ASTM D 6400 dan EN 13432).

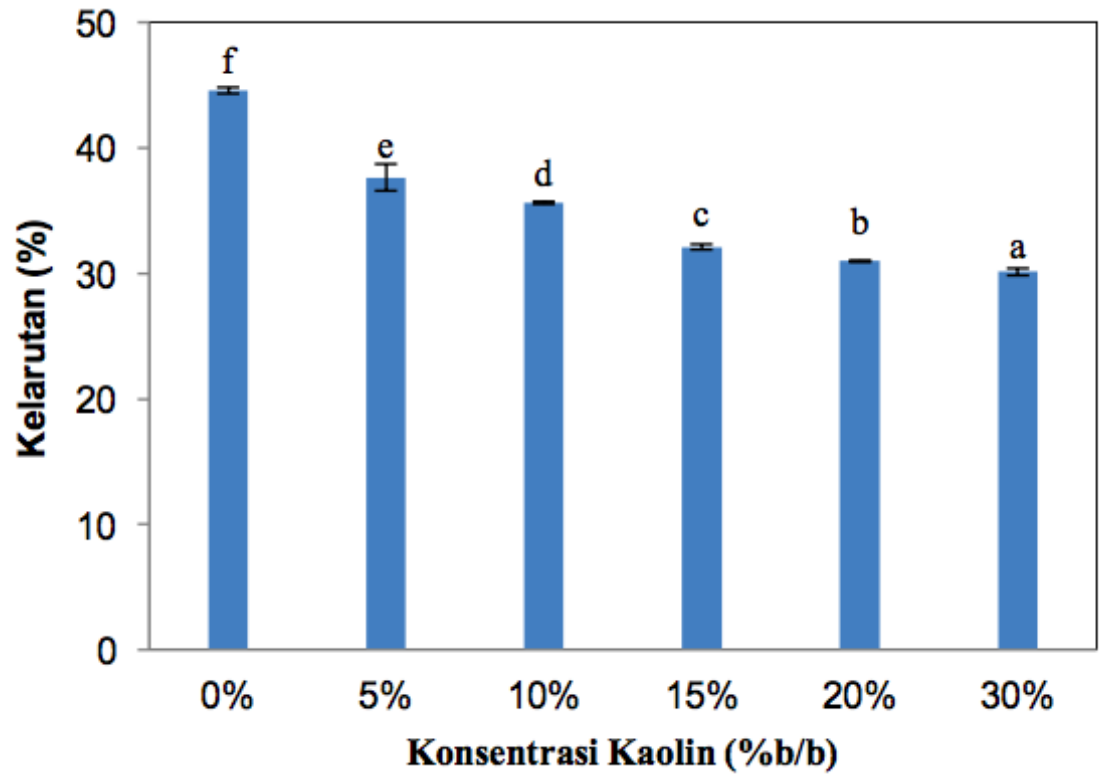

Keterangan: notasi huruf yang berbeda menunjukkan beda nyata $(p<0,05)$ berdasarkan Uji Tukey HSD

Gambar 7. Hubungan Penambahan Kaolin Terhadap \% Kelarutan Bioplastik 


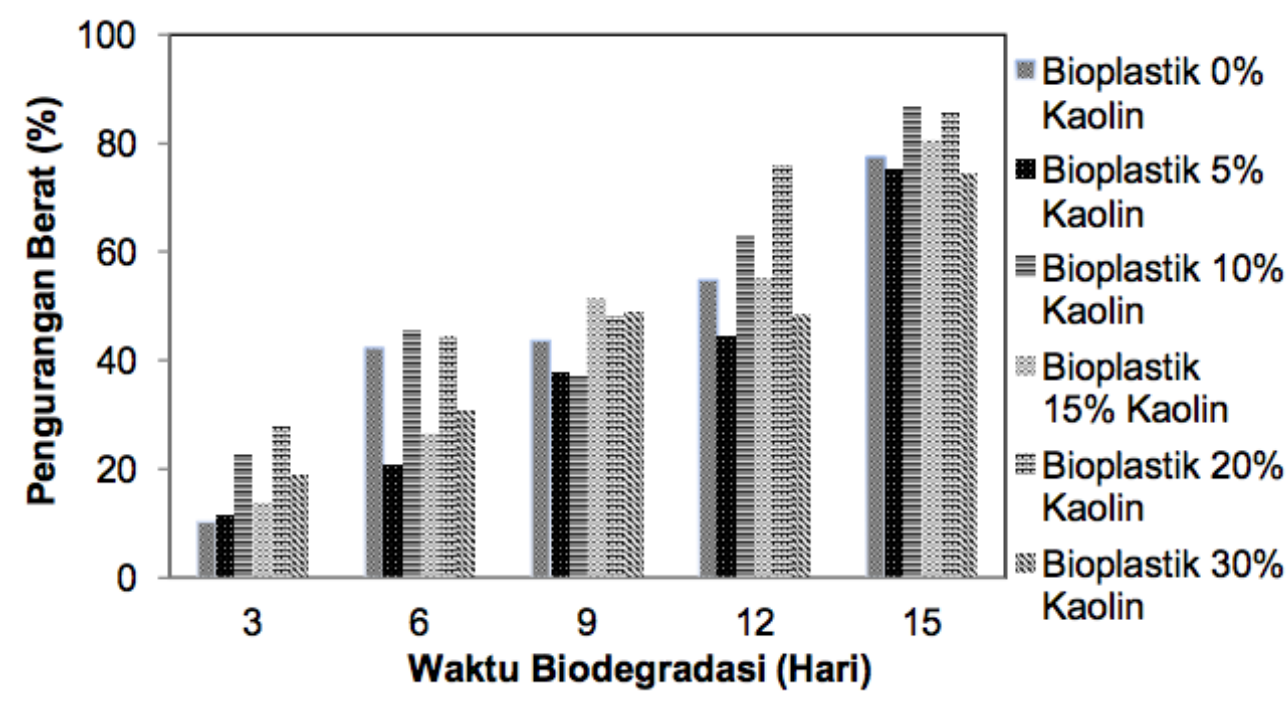

Gambar 8. Diagram Pengurangan Berat Bioplastik Selama 15 Hari

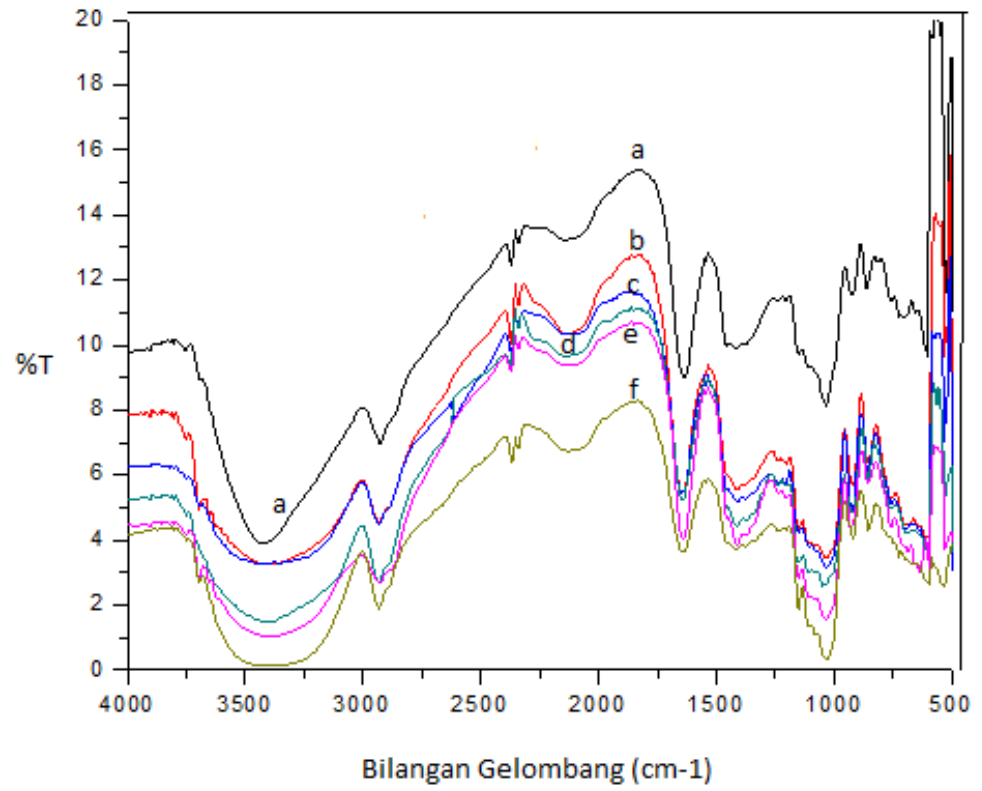

Gambar 9. Spektra IR (a). Bioplastik 0\% (b/b) Kaolin, (b). Bioplastik 5\% (b/b) Kaolin, (c). Bioplastik 10\% (b/b) Kaolin, (d). Bioplastik 15\% (b/b) Kaolin, (e). Bioplastik 20\% (b/b) Kaolin, (f). Bioplastik 30\% (b/b) Kaolin

Bioplastik yang dihasilkan dianalisis menggunakan Fourier Transform-Infra Red (FTIR) untuk mengetahui perubahan gugus fungsi yang terkandung dalam bioplastik. Gambar 9 menunjukkan bahwa bioplastik tanpa penambahan kaolin dibandingkan dengan bioplastik yang ditambahkan kaolin, tidak ada perbedaan serapan yang menonjol. Penambahan kaolin pada pati ubi nagara hanya menyebabkan penurunan nilai transmitansi. Gambar 9 (a) menunjukkan bahwa mula-mula dari hasil FTIR bioplastik tanpa kaolin terlihat adanya serapan gugus $\mathrm{OH}$ pada bilangan gelombang $3300 \mathrm{~cm}^{-1}$ namun dalam intensitas serapan yang sangat kecil. Gugus $\mathrm{OH}$ ini berasal dari unit glukosa, gliserol dan kaolin. Hal ini sesuai dengan (Ma, Chang, Yang, \& Yu, 2009), bahwa pita serapan pada panjang gelombang 3200-3500 cm-1 menunjukkan adanya gugus fungsi $\mathrm{OH}$. Setelah ditambahkan 
Tabel 1. Hasil Aalisa FTIR Terhadap Gugus Utama Bioplastik dan Perbandingannya

\begin{tabular}{|c|c|c|c|c|c|c|c|}
\hline \multirow{3}{*}{$\begin{array}{l}\text { Gugus } \\
\text { Fungsi }\end{array}$} & \multicolumn{7}{|c|}{ Bilangan Gelombag (1/cm) } \\
\hline & \multirow{2}{*}{$\begin{array}{c}\text { Bioplastik } \\
\text { Standar }\end{array}$} & \multicolumn{6}{|c|}{ Konsentrasi Kaolin } \\
\hline & & $0 \%$ & $5 \%$ & $10 \%$ & $15 \%$ & $20 \%$ & $30 \%$ \\
\hline $\begin{array}{l}\mathrm{O}-\mathrm{H} \\
\text { (ikatan } \\
\text { hidrogen) }\end{array}$ & $\begin{array}{l}3200- \\
3500\end{array}$ & 3371,57 & 3417,86 & 3307 & 3356,40 & 3422,43 & 3387 \\
\hline $\begin{array}{l}\text { C-H (tipe } \\
\text { senyawa } \\
\text { alkane) }\end{array}$ & $\begin{array}{l}2850- \\
3000\end{array}$ & 2924,90 & 2931,80 & 2931,80 & 2931,80 & 2931,80 & 2931,80 \\
\hline $\begin{array}{l}\text { Siklik } \\
\text { piran }\end{array}$ & $\begin{array}{l}1600- \\
1680\end{array}$ & 1635,64 & 1635,64 & 1635,64 & 1651,07 & 1635,64 & 1651,07 \\
\hline $\mathrm{C}-\mathrm{O}$ & $1050-126$ & 1049,28 & - & - & - & - & - \\
\hline $\mathrm{Si}-\mathrm{O}$ & 1033 & - & 1033,85 & 1033,85 & 1033,85 & 1033,85 & 1033,85 \\
\hline
\end{tabular}

kaolin intensitas serapan bertambah lebar, meningkat, dan cukup tajam. Seiring dengan peningkatan jumlah kaolin yang ditambahan intensitas serapan $\mathrm{OH}$ semakin melebar. Bentuk puncak yang melebar serta transmitansi yang mendekati nilai $0 \%$ menunjukkan bahwa jumlah gugus fungsi - $\mathrm{OH}$ yang terdapat dalam sampel bioplastik dengan peningkatan kadar kaolin sangat banyak. Serapan gugus $\mathrm{OH}$ mengalami pelebaran karena terjadi peningkatan jumlah ikatan hidrogen, sedangkan ikatan hidrogen terjadi ketika sebuah molekul atom $\mathrm{O}$ yang terdapat dalam kaolin berinteraksi dengan atom $\mathrm{H}$ dari amilosa dan amilopektin.

Tabel 1 menunjukkan bahwa bioplastik dari pati ubi nagara dengan kaolin sebagai penguat serta gliserol sebagai plasticizer memiliki serapan utama yang terdapat pada bilangan gelombang sekitar 1033,85 $\mathrm{cm}^{-1}, 1050 \mathrm{~cm}^{-1}, 1630 \mathrm{~cm}^{-1}$, $2930 \mathrm{~cm}^{-1}$, dan $3300 \mathrm{~cm}^{-1}$. Pada bioplastik $0 \%$ kaolin terdapat serapan pada bilangan gelombang $1049,28 \mathrm{~cm}^{-1}$ yang merupakan gugus spektrum regangan $\mathrm{C}-\mathrm{O}$ dari ikatan grup C-O-C. Ikatan C-O-C ini berasal dari unit glukosa pada pati yang digunakan sebagai matriks dalam penelitian ini. Menurut Wang, Zhang, Han, \& Bai, (2009), ikatan C-O-C berasal dari cincin anhydroglucose starch. Namun pada bioplastik dengan penambahan kaolin muncul serapan pada biangan gelombang $1033,85 \mathrm{~cm}^{-1}$ yang menunjukkan vibrasi ulur Si-O (Sunardi, Arryanto, \& Sutarno,
2010). Perubahan ini kemungkinan terjadi karena adanya penambahan kaolin maka atom $\mathrm{O}$ pada gugus $\mathrm{C}-\mathrm{O}$ dari pati akan berikatan dengan atom Si pada kaolin. Ikatan Si-O ini lebih kuat jika dibandingkan dengan ikatan $\mathrm{C}-\mathrm{O}$ sehingga serapan yang muncul adalah serapan vibrasi ulur Si-O.

Daerah serapan pada bilangan gelombang $1630 \mathrm{~cm}^{-1}$ merupakan jenis ikatan siklik piran. Ikatan siklik piran ini berasal unit glukosa penyusun pati. Menurut Pratomo \& Rohaeti, (2011), puncak vibrasi daerah $1630 \mathrm{~cm}^{-1}$ menunjukkan daerah yang berikatan secara siklik atau bentuk cincin aromatik. Pita serapan pada bilangan gelombang $2930 \mathrm{~cm}^{-1}$ menunjukkan vibrasi yang khas untuk gugus $\mathrm{C}-\mathrm{H}$. ikatan $\mathrm{C}-\mathrm{H}$ ini berasal dari pati dan juga gliserol yang digunakan pada penelitian ini. Hal ini sesuai dengan Wang et al., (2009) bahwa pita serapan $2930 \mathrm{~cm}^{-1}$ merupakan serapan dari gugus $\mathrm{C}-\mathrm{H}$ dengan cincin metana atom hidrogen. Namun, terdapat pergeseran beberapa bilangan gelombang puncak yaitu pada serapan gugus $\mathrm{OH}$ pada $3371,57 \mathrm{~cm}^{-1}$ menjadi $3417,86 \mathrm{~cm}^{-1}$, serapan gugus $\mathrm{C}-\mathrm{H}$ pada $2924,09 \mathrm{~cm}^{-1}$ menjadi $2931,80 \mathrm{~cm}^{-1}$ dan serapan gugus siklik piran pada $1635,64 \mathrm{~cm}^{-1}$ menjadi $1651,07 \mathrm{~cm}^{-1}$. Pergeseran bilangan gelombang ini terjadi karena adanya perubahan tingkat energi. Energi mengalami peningkatan dikarenakan adanya ikatan yang lebih kuat ketika bioplastik dari pati ditambahkan dengan kaolin. Ikatan yang lebih kuat ini 
berasal dari ikatan hidrogen yang terdapat dalam matriks bioplastik setelah ditambahkan dengan kaolin.

\section{KESIMPULAN}

Berdasarkan hasil penelitian menunjukkan bahwa semakin banyak kaolin yang ditambahkan dapat menurunkan nilai kadar air, laju transmisi uap air, daya serap air, kelarutan dan elongasi bioplastik. Peningkatan jumlah kaolin juga meningkatkan nilai kuat tarik dan ketebalan bioplastik yang dihasilkan. Berdasarkan data kuat tarik maka jumlah penambahan kaolin optimum dalam pembuatan bioplastik adalah pada konsentrasi kaolin $30 \%$ (b/b) dengan nilai kuat tarik sebesar 2,194 $\mathrm{N} / \mathrm{mm}^{2}$. Berdasarkan standar kuat tarik yang dihasilkan bioplastik dari pati ubi nagara dengan penguat kaolin dapat digunakan sebagai kemasan makanan.

\section{DAFTAR PUSTAKA}

Akbar, F., Anita, Z., \& Harahap, H. (2013). Pengaruh waktu simpan film plastik biodegradasi dari pati kulit singkong terhadap sifat mekanikalnya. Jurnal Teknik Kimia USU, 2(2).

Amaliya, R. R., \& Putri, W. D. R. (2013). Karakterisasi edible film daripati jagung dengan penambahan filtrat kunyit putih sebagai antibakteri [in press juli 2014]. Jurnal Pangan dan Agroindustri, 2(3), 43-53.

Balakrishna, N. S., Ismail, H., \& Othman, N. (2014). Polypropylene/rattan powder/kaolin hybrid composites: Processing, mechanical and thermal properties. PolymerPlastics Technology and Engineering, 53(5), 451-458. doi:10.1080/03602559.2013.84483 3

Darni, Y., Lestari, H., Lismeri, L., Utami, H., \& Azwar, E. (2018). Aplikasi mikrokristalin selulosa dari batang sorgum sebagai pengisi pada sintesis film bioplastik. Jurnal Rekayasa Kimia \& Lingkungan, 13(1), 15-23.
Díez-Pascual, A. M., \& Díez-Vicente, A. L. (2014). Poly(3-hydroxybutyrate)/zno bionanocomposites with improved mechanical, barrier and antibacterial properties. International journal of molecular sciences, 15(6), 10950-10973. doi:10.3390/ijms150610950

Fadeyibi, A., Osunde, Z. D., Egwim, E. C., \& Idah, P. A. (2017). Performance evaluation of cassava starch-zinc nanocomposite film for tomatoes packaging. Journal of Agricultural Engineering, 48(3), 137-146.

González-Gutiérrez, J., Partal, P., GarcíaMorales, M., \& Gallegos, C. (2011). Effect of processing on the viscoelastic, tensile and optical properties of albumen/starch-based bioplastics. Carbohydrate polymers, 84(1), 308-315.

Kamsiati, E., Herawati, H., \& Purwani, E. Y. (2017). Potensi pengembangan plastik biodegradable berbasis pati sagu dan ubikayu di indonesia. Jurnal Penelitian dan Pengembangan Pertanian, 36(2), 67-76.

Kasim, A., Abral, H., Asben, A., \& Sudirman, S. (2018). Pembuatan dan karakterisasi komposit bioplastik berbasis filler cellulose micro fibers rami. Jusamil Indonesian Journal of Materials Science, 19(2), 66-72.

Ma, X., Chang, P. R., Yang, J., \& Yu, J. (2009). Preparation and properties of glycerol plasticized-pea starch/zinc oxide-starch bionanocomposites. Carbohydrate polymers, 75(3), 472-478.

North, E. J., \& Halden, R. U. (2013). Plastics and environmental health: The road ahead. Reviews on environmental health, 28(1), 1-8. doi:10.1515/reveh-2012-0030

Pratomo, H., \& Rohaeti, E. (2011). Bioplastik nata de cassava sebagai bahan edible film ramah lingkungan. Jurnal Penelitian Saintek, 16(2), 172-190.

Ratnayake, W. S., \& Jackson, D. S. (2008). Starch gelatinization. Advances in 
food and nutrition research, 55, 221-268.

Safitri, I., Riza, M., \& Syaubari, S. (2016). Uji mekanik plastik biodegradable dari pati sagu dan grafting poly (nipam)-kitosan dengan penambahan minyak kayu manis (cinnamomum burmannii) sebagai antioksidan. Jurnal Litbang Industri, 6(2), 107-116.

Salmah, H. I., Ismail, H., \& Bakar, A. (2005). A comparative study on the effects of paper sludge and kaolin on properties of polypropylene/ethylene propylene diene terpolymer composites. Iranian Polymer Journal, 14(8), 705713.

Sunardi, S., Arryanto, Y., \& Sutarno, S. (2010). Adsorption of gibberellic acid onto natural kaolin from tatakan, south kalimantan. Indonesian Journal of Chemistry, 9(3), 373-379.

Suryanto, H., Kharismawan, $F$., Rahmawan, A., Sahana, R., Muhajir, M., \& Yanuhar, U. (2019). Influence of nanoclay on thermal decomposition of biocomposite matrix starch/carrageenan blend. Paper presented at the IOP Conference Series: Materials Science and Engineering.

Suryanto, H., Rahmawan, A., Sahana, R., Muhajir, M., \& Yanuhar, U. (2019). Influence of carrageenan on the mechanical strength of starch bioplastic formed by extrusion process. Paper presented at the IOP Conference Series: Materials Science and Engineering.

Wahyuningtiyas, N. E., \& Suryanto, H. (2017). Analysis of biodegradation of bioplastics made of cassava starch. Journal of Mechanical Engineering Science and Technology, 1(1), 24-31.

Wang, N., Zhang, X., Han, N., \& Bai, S. (2009). Effect of citric acid and processing on the performance of thermoplastic starch/montmorillonite nanocomposites. Carbohydrate polymers, 76(1), 68-73.
Xie, F., Pollet, E., Halley, P. J., \& Averous, L. (2013). Starch-based nanobiocomposites. Progress in Polymer Science, 38(10-11), 1590-1628.

Zainuddin, S., Ahmad, I., \& Kargarzadeh, H. (2013). Cassava starch biocomposites reinforced with cellulose nanocrystals from kenaf fibers. Composite Interfaces, 20(3), 189-199. 